Для отримання циліндричної поверхні (рис. 2 б, г, д) проходи необхідно розташовувати на рівній відстані один від одного. При чому, чим менший радіус циліндричності поверхні потрібно отримати, тим менший крок має бути між сусідніми зонами опромінення. Для отримання параболічної (рис. 2 в), та подібних поверхонь, необхідно застосовувати варіювання кроку між зонами опромінення за певним законом. Зміна напрямку кривизни зразка (рис. 2 г, д) досягалася за рахунок опромінення зразка з протилежних сторін. Оскільки в даному випадку реалізується формувальний механізм градієнту температур, то зразок формувався на зустріч лазерному променю.

Слід зазначити, що додатковим фактором формування може бути застосування криволінійних траєкторій лазерних проходів. Однак, це ускладнить напружено-деформований стан зразка і тому, використання криволінійних траєкторій лазерних проходів, потребує додаткового вивчення.

\title{
Література:
}

1. Кагляк О.Д., Головко Л.Ф., Гончарук О.О. «Лазерне формоутворення просторових металевих конструкцій», Східно-європейський журнал передових технологій. - 2009. - № 6/1(42). Рp. 4-11.

2. Кагляк О. Д. Розроблення програмного модуля вибору режиму обробки для лазерного формування листових матеріалів. Автоматизація та комп'ютерно-інтегровані технології - 2019 VI Міжнародна науковопрактична конференція молодих учених, аспірантів і студентів АКІТ 2019 (Київ, 23-24 квітня 2019 р.) Київ, 2019. С. 124-127.

DOI https://doi.org/10.30525/978-9934-588-79-2-1.32

\section{МОДЕЛІ ФОРМУВАННЯ БУЛЬБАШОК У ГІРНИЧИЙ МАШИНІ ДЛЯ УТИЛІЗАЦІЇ ВТОРИННОЇ ЕНЕРГІЇ}

\author{
Кірсанов М. В. \\ головний конструктор проекту \\ Інституту геотехнічної механіки імені М. С. Полякова \\ Національної академії наук Украӥни \\ м. Дніпро, Україна
}

Сучасні вимоги до ощадливого використання енергоресурсів приводять до необхідності розробки технічних розв'язків, спрямованих на використання вторинних джерел теплової енергії різного походження. 128 
До таких джерел ми відносимо теплоту вторинних енергетичних ресурсів (ВЕР) основного технологічного встаткування в металургійній, гірничодобувній і вугільній промисловості, а також теплоту надр Землі. Значення температури носія енергії ВЕР може перебувати в досить великому діапазоні значень. Але чим нижче значення температури, тем більший потік (витрата) ВЕР може бути корисно використаний. На підприємствах вугільної промисловості України $є$ значні обсяги ВEР невисокого температурного потенціалу, які доцільно використовувати в складі шахтних енергетичних комплексів (ШЕК) [1, стор. 7]. Традиційне використання ВЭР невисокого температурного потенціалу пов'язане з теплопостачанням.

Через сезонний характер навантажень теплопостачання стає актуальним увага до процесів перетворення теплової енергії нагрітої води в корисну механічну роботу (електроенергію). Тому становлять інтерес процес по перетворенню теплової енергії нагрітої води в електроенергію в машинах, що працюють за гідро-паровим термодинамічним (або трикутним) циклом [2, стор. 68]. Перспективи застосування турбін (машин), що працюють на основі трикутного циклу, у складі ШЕК розглянуті в [3, стор. 87].

Нагадаємо, що машина є пристрій, який виконує механічний рух для перетворення енергії,матеріалів та інформації з метою заміни або полегшення фізичної або розумової праці людини [4, стор.17]. Класифікацію машин надано в [4, стор.17-18]. Враховуючи джерело енергії, грунтуючись на вище вказаній класифікації, робимо висновок, що установки, які працюють на основі трикутного циклу, у складі ШЕК являють собою один з варіантів гірничої машини, що утилізує енергію вторинних ресурсів (ЕГМ). Робота ЕГМ полягає в наступному. У соплах ЕГМ відбувається розширення робочого середовища (нагрітої до певної температури $\mathrm{T}_{0}$ води) в область двофазних станів на діаграмі «p-v». Сопла встановлені на периферії радіальних трубок, по яких подається нагріта вода через вісь колеса. Це колесо розташовано у циліндрі з горизонтальною віссю відносно поверхні фундаменту, В циліндрі підтримується необхідний рівень вакууму, що визначається температурою води охолодження у конденсаторі.

Після виходу із сопел двофазний (пароповітряна суміш та краплі води) потік направляється в конденсатор, розташований під циліндром. Внутрішній простір циліндру та конденсатору спільний. У конденсаторі замикається контуру циркуляції робочого тіла у трикутному термодинамічному циклі. Для проектування ЕГМ необхідно розв'язати ряд наукових завдань, зв'язаних, наприклад, з визначенням параметрів пароповітряних бульбашок, які служать центрами скипання в 
соплах виходячи з гетерогенної теорії, яку ми залучаємо, враховуючи невисоку температуру ВЕР. При аналізі літературних джерел встановлено, що вибір радіуса бульбашки порядку одного мікрона береться довільно без урахування умов їх формування [5, стор. 137]. Ситуація 3 відсутністю науково обгрунтованої методики визначення параметрів пароповітряних бульбашок на вході в сопло турбіни стримує використання ЕГМ у складі ШЕК. Отже, встановлення механізму формування бульбашок у конденсаторі $\epsilon$ актуальним науковим завданням. Проаналізувавши різні причини гетерогенного творення зародків кипіння, доходимо висновку, що всі вони, у остаточному підсумку, приводять до виникнення в спочатку чистій (бульбашки відсутні) воді пароповітряних бульбашок за рахунок або розчиненого у воді повітря, або, того повітря, що дифундує з вільної поверхні води у конденсаторі.

Розглянемо весь кругообіг газової фази в циклі ЕГМ. У літературі, наявної в нашому розпорядженні, у такій постановці питання не вивчалася, і вся увага зосереджувала на розрахунках скипання й руху в соплі потоку нагрітої води з бульбашками. Враховуючи велику й розвинену поверхню між водою й газопаровою фазою в конденсаторі, досить тривалий час проходження цього двофазного потоку через конденсатор, падіння двофазного (краплі та пароповітряна суміш) на поверхню води в конденсаторі можна прийняти наступну фізичну модель. Утворення пароповітряних бульбашок-зародків кипіння у верхньому шарі рідкої фази води в конденсаторі можна пояснити захопленням повітря при падінні крапель на поверхню води. Процес «захоплення» повітря при падінні крапель на поверхню води в конденсаторі становить зміст першого етапу формування пароповітряних бульбашок, які стануть зародками наступного скипання в соплі машини. Відомо, що при падінні краплі і їх подальшого занурення у воду на поверхні води утворюється маленька «кишеня». Ця «кишеня» при своєму замиканні за рахунок сил гравітаційного обвалення іï країв i сил поверхневого натягу формує бульбашку вже під поверхнею води [6, p. R3-3]. Для умов ЕГМ газовий склад «кишені» і наступної бульбашки визначається складом пароповітряної суміші над поверхнею води. На основі вищевикладеного, перший етап формування пароповітряних бульбашок можна математично промоделювати рівняннями

$$
\begin{gathered}
p_{S}\left(T_{c}\right)+\rho_{a} \cdot\left(R_{u g} / \mu_{a}\right) \cdot T_{c}=\left(2 \cdot \sigma_{w}\right) / b_{c}, \\
m_{c}=\rho_{a} \cdot(4 / 3) \cdot \pi \cdot b_{c}^{3},
\end{gathered}
$$


де $p_{s}\left(T_{c}\right)$ - тиск насичених пар води в конденсаторі при температурі $T_{c}$,

$R_{u g}$ - універсальна газова постійна,

$\rho_{a}$ - щільність повітря в пароповітряній суміші в конденсаторі,

$\mu_{a}$ - молекулярна маса повітря,

$\sigma_{\mathrm{w}}-$ коефіцієнт поверхневого натягу води,

$b_{c}$ - радіус бульбашки,

$m_{c}-$ маса повітря у пароповітряній бульбашці.

Пароповітряна бульбашка із параметрами $b_{c}$ i $m_{c}$, які визначаються рівняннями (1) і (2), формується в процесі занурення краплі води у верхній шар води в конденсаторі. Далі бульбашка із параметрами по (1) - (2), яка утворюється при зануренні краплі, починає стискатися зовнішнім гідростатичний тиском досить тонкого товщиною, порядку одного міліметра, верхнього шару води у конденсаторі. Таким чином бульбашка стискається до радіуса, обумовленого рівнянням механічної рівноваги, подібного (1). Потім пароповітряні бульбашки проходять теплообмінник для нагрівання води за рахунок теплоти ВЕР і попадають разом з потоком нагрітої води на вхід радіальних трубок, які ведуть до сопел. Радіус $\mathrm{b}_{0}$ бульбашки на вході в сопло ЕГМ після проходження трубок можна визначити розв'язком рівняння механічної рівноваги

$$
p_{a}\left(3 \cdot m_{c} /\left(4 \cdot \pi \cdot b_{0}^{3}\right), T_{0}\right)+p_{s}\left(T_{0}\right)=p_{E R M}+\left(2 \cdot \sigma_{w}\right) / b_{0},
$$

де $T_{0}$ - температура нагрітої води (після теплообмінника) на вході в сопло ЕГМ;

$p_{E R M}$ - тиск води на вході в сопло ЕГМ;

$p_{a}(\rho, T)$ - рівняння стану повітря для високих тисків [7, стор. 46].

Таким чином, для визначення радіуса пароповітряних бульбашок у вхідному перетині сопла ЕГМ на основі гетерогенної теорії творення зародків кипіння й фундаментальних законів механіки й термодинаміки розроблена система алгебраїчних рівнянь (1) - (3). На основі цієї системи рівнянь можна вивчати вплив параметрів ВЕР на радіус бульбашок на вході в сопло ЕГМ. Новизна роботи полягає у пропонуванні конкретного механічного процесу «захоплення» повітря верхнім шаром води в конденсаторі ЕГМ та його математичної формалізації.

Шляхом аналізу результатів розв'язку системи (1) - (3) слід установити залежність радіуса пароповітряних бульбашок у конденсаторі й на вході в сопло ЕГМ. Це дозволить підвищити точність і адекватність встановлення конструктивних розмірів елементів сопла машини залежно від параметрів робочого тіла в ключових точках його контуру циркуляції. 


\title{
Література:
}

1. Булат А.Ф., Чемерис И.Ф. Научно-технические основы создания шахтных когенерационных энергетических комплексов. Киев : Наук. думка, 2006. - 176с.

2. Зысин, В.А. Комбинированные парогазовые установки и циклы / Р.И. Нигматулин. - М.-Л.: Госэнергоиздат, 1962. - 187с.

3. Кирсанов М.В., Губинский М.В. Перспективы применения гидропаровой турбины для утилизации тепла шахтного энергокомплекса. Металлургическая и горнорудная промышленность. 2013 № 6. С. 87-90.

4. Кіницький Я.Т. Теорія механізмів і машин. Київ: Наук. думка, $2002661 \mathrm{c}$.

5. Нигматулин, Р.И. Динамика многофазных сред. Ч.ІІ / Р.И. Нигматулин. - М. : Наука, 1987. - 360с.

6. Tran T., de Maleprade E., Sun C., Lohse D. Air entrainment during impact of droplets on liquid surfaces. Journal of Fluid Mechanics. 2013. v. 726, R3. p. R3-1 - R3-11.

7. Вассерман А.В. Аналитическое описание теплофизических свойств воздуха и его компонентов и составление таблиц справочных данных. Технические газы. 2009 № 6. С. 43-53.

DOI https://doi.org/10.30525/978-9934-588-79-2-1.33

\section{О КОЛЕБАНИЯХ СЫПУЧЕЙ СРЕДЫ С СУЩЕСТВЕННЫМ ПРОЯВЛЕНИЕМ ВЯЗКИХ СВОЙСТВ}

\author{
Ковбаса В. П. \\ доктор технических наук, профессор, \\ Винницкого национального аграрного университета \\ Цуркан О. В. \\ кандидат технических наук, дочент, \\ Винницкого национального аграрного университета \\ 2. Винница, Украина \\ Соломка А. В. \\ кандидат технических наук \\ Национального университета биоресурсов \\ и природопользования Украинь \\ г. Киев, Украина
}

